\title{
COMPARATIVE EVALUATION OF THE CYTOTOXIC EFFECT OF DIFFERENT INTRACANAL MEDICAMENTS
}

\author{
Sherouk Hussein Hassan Hussein ${ }^{1}$, Nelly Mohamed Abdelsalam Mostafa ${ }^{2}$, \\ Enas Mahmoud Hegazy ${ }^{3}$, Dalia Mukhtar Fayyad ${ }^{4}$, Abeer Moustafa Darrag ${ }^{5}$
}

DOI: $10.21608 /$ dsu.2021.46129.1051

Manuscript ID: DSU-2010-1051

\section{KEYWORDS}

Cytotoxicity,

Calcium hydroxide,

Double antibiotic paste,

methyl thiazolyl tetrazolium assay,

Neem oil,

apoptosis/necrosis assay.

- E-mail address:

dentist993@hotmail.com

1. Assistant Lecturer in Endodontic Department, Faculty of Dentistry, Suez Canal University

2. Lecturer in Endodontic Department, Faculty of Dentistry, Suez Canal University

3. Associate Professor of Oral Biology, Faculty of Dentistry, Suez Canal University

4. Professor of Endodontics, Faculty of Dentistry, Suez Canal University

5. Professor of Endodontics, Faculty of Dentistry, Tanta University

\begin{abstract}
Introduction: intracanal medicaments have an important role in disinfecting of the pulp space and in endodontic regenerative procedures. These medications come in close contact with the periradicular tissue, thus their degradation products must be biocompatible with the periapical tissue. Otherwise, these medicaments will result in intense inflammatory reaction. Aim of the study: The purpose of this in vitro study was to evaluate and compare the cytotoxicity of three intracanal medications; Neem oil, double antibiotic paste (DAP) and calcium hydroxide $\left(\mathrm{Ca}(\mathrm{OH})_{2}\right)$. Materials and Methods: Immortalized human gingival fibroblast cells were retrieved from the cell bank and then cultured. Three different intracanal medications (Neem oil, DAP, $\mathrm{Ca}(\mathrm{OH})_{2}$ ) were added to the cultured cells. Cell viability was evaluated using 3-(4, 5-dimethylthiazol-2-yl)-2,5-diphenyl-2H-tetrazolium bromide (MTT) and Apoptosis/necrosis assays. Statistical analysis was performed using One-way ANOVA and post-hoc Tukey test. Results: $\mathrm{Ca}(\mathrm{OH})_{2}$ recorded the highest significant cytotoxicity followed by Neem oil, then DAP which recorded the lowest significant cytotoxicity. Cytotoxicity of the three intracanal medicaments used were directly proportional to their concentrations Conclusion: DAP could be better recommended as intracanal medicament in regenerative endodontic procedures because of its biocompatibility compared to the other tested medications.
\end{abstract}

\section{INTRODUCTION}

Intracanal medicaments play a complementary role in root canal therapy as they help eliminating the remaining microorganisms in the root canal system that have not been removed by the chemo-mechanical preparation including instrumentation and irrigation processes. They also have an important role in disinfecting of the pulp space in the noninstrumented endodontic regenerative procedures ${ }^{(\mathbf{1}, 2)}$.

These medications come in close contact with the periradicular tissue, thus their degradation products must be biocompatible with the periapical tissue ${ }^{(3)}$. Otherwise, these medicaments will result in intense inflammatory reaction, mediated by various inflammatory mediators which in turn can induce tissue destruction and interfere with periradicular healing ${ }^{(4)}$. 
Biocompatibility of these intracanal medicaments can be determined by many parameters such as genotoxicity, mutagenicity, carcinogenicity, cytotoxicity or histocompatibility. It is impossible to biologically characterize the materials by using a single test and their properties need to be evaluated both in vitro and in vivo tests in a structured approach ${ }^{(5,6)}$. Cytotoxicity and cell viability assays are used in a broad spectrum in the fields of toxicology and pharmacology. The choice of assay method is important in the assessment of the interaction type $\mathrm{e}^{(7)}$.

Methyl thiazolyl tetrazolium assay is a colorimetric assay to determine cell viability and cytotoxicity ${ }^{(8)}$. It is based on the ability of mitochondrial succinate dehydrogenases in viable cells to reduce a yellow tetrazolium dye MTT (3-\{4, 5-dimethylthiazol-2-yl\}-2, 5-diphenyltetrazolium bromide) to violet formazan product which is detected spectrophotometrically. The healthy cells exhibit high rates of MTT reduction to formazan while the dead cells fail to do so. Viability in the MTT assay depends on the quantification of formazan at $540 \mathrm{~nm}$ which is directly linked with the number of viable cells. High purple color intensity represents higher cell viability while the decrease in purple color intensity implies the reduced cell number and thus cytotoxicity of the given substance ${ }^{(9)}$.

Apoptosis is a programmed mode of cell death that can be triggered by both extrinsic and intrinsic factors ${ }^{(\mathbf{1 0})}$. The annexin V assay is the most frequently used method to visualize the early-stage apoptosis and to characterize the apoptotic cell populations by flow-cytometry ${ }^{(11,12)}$. The fluorescent probe annexin $\mathrm{V}$ is used for the quantification of apoptosis because it binds to negatively charged phospholipids like phosphatidylserine (PS). In an early stage of apoptosis, the PS molecule translocates from the inner part of the plasma membrane to the outer layer. Because necrotic cells also expose PS due to the loss of mem- brane integrity, apoptotic cells were distinguished from necrotic cells by propidium iodide (PI) labeling. PI is a vital stain frequently used to identify necrotic cells, based on the loss of membrane integrity. Apoptotic cells maintain their plasma membrane integrity during the major portion of the apoptotic process and become permeable to PI during secondary necrosis (13). In this way vital, apoptotic and dead cells can be distinguished on the basis of double-labeling for annexin V and PI, and analyzed either by flowcytometry or by fluorescence microscopy.

Triple antibiotic paste (TAP) which is a mixture of metronidazole, ciprofloxacin and minocycline was the first antimicrobial agent to be successfully applied guided in endodontic regeneration ${ }^{(14)}$. Double antibiotic paste (DAP), which is a combination of only metronidazole and ciprofloxacin, has been used successfully in endodontic regeneration and was suggested as a substitute to TAP to overcome the drawbacks of TAP including the discoloration effect of minocycline ${ }^{(15)}$.

However, the most widely used intracanal medicament in endodontic regeneration is calcium hydroxide $\left(\mathrm{Ca}(\mathrm{OH})_{2}{ }^{\left({ }^{16}\right)}\right.$. The application of $\mathrm{Ca}(\mathrm{OH})_{2}$ depends on its ability to neutralize microbial byproducts. $\mathrm{Ca}(\mathrm{OH})_{2}$ may result in chronic inflammation and cell necrosis in vivo due to its high $\mathrm{pH}$. In addition, $\mathrm{Ca}(\mathrm{OH})_{2}$ is not effective in completely eliminating bacteria from the dentinal tubules ${ }^{(17)}$.

The increasing number of antibiotic-resistant strains and the side effects caused by synthetic drugs ${ }^{(18)}$ has encouraged researchers to look for herbal alternatives. The worldwide growth of phytotherapy in preventive and curative programs has stimulated the application of different plant extracts in medical and dental fields. However, the accurate use of plants for therapeutic purposes is based on effectiveness, biocompatibility, and scientifical validation. 
Neem is a herbal medicament which possesses anti-inflammatory, antibacterial and anti-adherent effects ${ }^{(19)}$. It was recently applied as intracanal medicament with excellent antimicrobial effect ${ }^{(19)}$. Thus, this research aimed to compare the biocompatibility of Neem (as herbal intracanal medicaments), DAP and the commonly used root canal medicament $\mathrm{Ca}(\mathrm{OH})_{2}$ by using both MTT and Apoptosis/ necrosis cytotoxic assays. The null hypothesis was that there is no significant differences between the 3 tested medicaments at different concentrations.

\section{MATERIALS AND METHODS}

\section{Study design and sampling}

This study was conducted after the approval of the Research Ethics Committee (number 17/2017), Faculty of Dentistry, Suez Canal University, Ismailia, Egypt.

$f:$ is the effect size $=0.5 ; \alpha=0.05 ; \beta=0.2$; Power $=1-\beta=0.80$

MTT dye reduction assay sample size: according to sample size calculations a total sample size of 96 well was used, in which each concentration (M1, M2, M3, M4, M5) of each intracanal medication (A, $B, C)$ was represented by 6 wells and group (d) was represented by 6 wells.

Apoptosis/necrosis assay sample size: This procedure was performed in duplicates, where 500 $\mu \mathrm{L}$ siliconized tubes were used; each tube consisted of $4 \times 106$ cells at the start of the procedure to compensate for cell loss.

\section{MTT dye reduction assay}

\section{Specimens preparation and grouping}

The intracanal medications used for this study were calcium hydroxide paste (Meta Biomed,
Chungbuk, Korea), double antibiotic paste [1:1 mixture of Metronidazole (50 mg) (Sanofi-Aventis, Gentilly, France) and Ciprofloxacin (50 mg) (Bayer, Leverkusen, Germany) prepared with glycrol (50 $\mathrm{mL}$ )], and neem oil (UpNature, Nicosia, Cyprus). The three intracanal medications were initially prepared as a $10 \mathrm{mg} / \mathrm{mL}$ stock. For the doseresponse curve, the stock solutions were diluted in cell culture medium (DMEM) to achieve a total of five concentrations $(0.5,0.25,0.125,0.0625$, and $0.00781 \mathrm{mg} / \mathrm{mL}$ ) (Table 1).

Table 1: Variables of the study and levels of investigation for MTT

\begin{tabular}{|c|c|c|}
\hline Variable & Level & Referred to \\
\hline \multirow{4}{*}{$\begin{array}{c}\text { Type of intracanal } \\
\text { medication }\end{array}$} & A & $\begin{array}{l}\text { Group (A), Neem } \\
\text { Cells were grown in medium } \\
\text { conditioned by neem oil. }\end{array}$ \\
\hline & B & $\begin{array}{l}\text { Group (B), DAP } \\
\text { Cells were grown in medium } \\
\text { conditioned by double } \\
\text { antibiotic paste }\end{array}$ \\
\hline & $\mathbf{C}$ & $\begin{array}{l}\text { Group }(\mathbf{C}), \mathbf{C a}(\mathbf{O H})_{2} \\
\text { Cells were grown in medium } \\
\text { conditioned by calcium } \\
\text { hydroxide. }\end{array}$ \\
\hline & D & $\begin{array}{l}\text { Group (D), Control } \\
\text { Cells were grown in fresh } \\
\text { medium }\end{array}$ \\
\hline \multirow{5}{*}{$\begin{array}{c}\text { Concentration } \\
\text { (M) }\end{array}$} & $\mathbf{M}_{1}$ & Concentration of 0.5 \\
\hline & $\mathbf{M}_{2}$ & Concentration of 0.25 \\
\hline & $\mathbf{M}_{3}$ & Concentration of 0.125 \\
\hline & $\mathbf{M}_{4}$ & Concentration of 0.0625 \\
\hline & $\mathbf{M}_{5}$ & Concentration of 0.00781 \\
\hline
\end{tabular}

\section{Cell culture:}

Immortalized human gingival fibroblast cells were retrieved from the cell bank of Egyptian Company for Production of Vaccines (Vacsera). Cells were cultured as adherent monolayers in plastic tissue culture dishes in complete growth medium: Dulbecco's Modified Eagle Medium 
(DMEM high-glucose) (Merck, Darmstadt, Germany) supplemented with $10 \%$ fetal bovine serum (Sigma, Seelze, Germany), 2 ML-glutamine (Sigma, Seelze, Germany), penicillin G 100 mg/mL (Sigma, Seelze, Germany), streptomycin $100 \mu \mathrm{g} /$ $\mathrm{mL}$ (Sigma, Seelze, Germany) and 1\% Fungizone (Sigma, Seelze, Germany). Cells were preserved in an incubator (Thermo Fisher Scientific, Waltham, Massachusetts, USA) at $37^{\circ} \mathrm{C}$ in humidified $95 \%$ air and 5\% CO2 for $1 \mathrm{~h}$. Cell culture medium was refreshed each 2 or 3 days until the cells reached $80 \%$ confluence for optimal cell harvesting, and then cells were detached with $0.5 \%$ (w/v) trypsinEDTA for subcultures. Growing cells were diluted in fresh medium and seeded into 96-well plates $\left(1.0 \times 10^{4}\right.$ cells/well $)$. After incubation for $24 \mathrm{~h}$, the medium was aspirated from all wells and replaced blindly with $100 \mu \mathrm{L} /$ well of serial dilutions of the used intracanal medicaments $(0.05,0.025,0.125$, 0.0625 and $0.00781 \mathrm{mg} / \mathrm{mL}$ ), or control medium. Cells were incubated for another $24 \mathrm{~h}$ (six wells/ five serial dilutions/ three intracanal medicaments). All steps were carried out under aseptic conditions (vertical cleanroom workbench BIO-CL).

\section{MTT dye reduction assay}

MTT dye [3-(4, 5-dimethylthiazol-2-yl)-2,5diphenyltetrazolium bromide] (Abcam, USA) was prepared as $0.5 \mathrm{mg} / \mathrm{mL}$ in ice-cold phosphate-buffered saline (PBS) at $37^{\circ} \mathrm{C}$ just before use. To determine cell viability, a total of $10 \mu \mathrm{L}$ MTT dye was added to each well and the plate was incubated at $37^{\circ} \mathrm{C}$ in air containing $5 \% \mathrm{CO} 2$ and at $95 \%$ relative humidity for $2-12 \mathrm{~h}$ to allow mitochondrial succinate dehydrogenases in viable cells to reduce intracellular soluble yellow tetrazolium dye MTT to insoluble violet formazan dye (Fig. 1). Formazan was solubilized before recording absorbance readings by adding $100 \mu \mathrm{L}$ dimethyl sulfoxide (DMSO) detergent reagent to each well to avoid formazan accumulation as an insoluble precipitate inside cells as well as being deposited near the cell surface and in the culture medium ${ }^{(20)}$. After 10 minutes at room temperature to ensure that all crystals were dissolved, optical densities of each plate were read with microplate reader at 550-600 $\mathrm{nm}$. All assays were performed in triplicates to ensure reproducibility. The absorption value obtained with the untreated fibroblasts as a control was deemed to indicate $100 \%$ viability. The percentage of viable cells was determined using the following formula:

\section{Percentage of Viable Cells $=(A / B) \times 100$}

Where $\mathrm{A}=$ viable cells in the experimental well and $\mathrm{B}=$ viable cells in the control well. More than $90 \%$ cell viability considered as noncytotoxic, $60 \%$ to $90 \%$ as slightly cytotoxic, $30 \%-59 \%$ as moderately cytotoxic, and less than $30 \%$ cell viability considered as highly cytotoxic ${ }^{(21)}$.

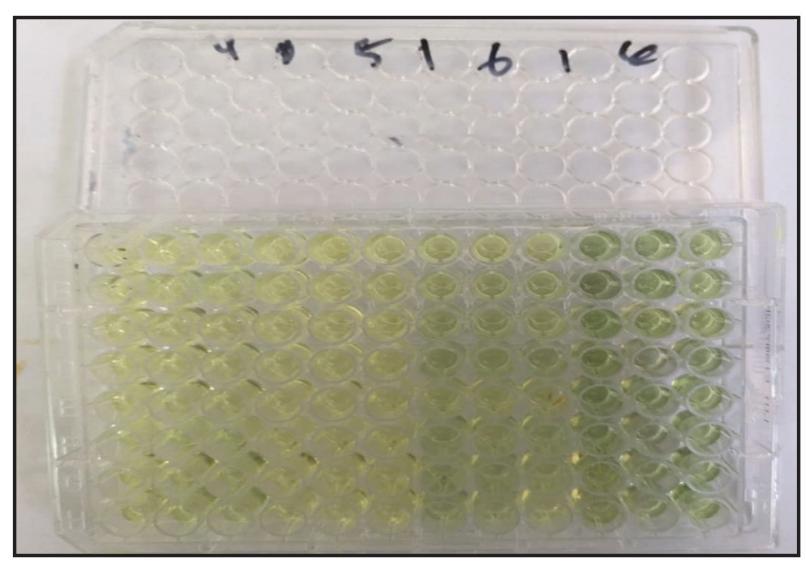

Fig. (1) A photograph showing reduction of intracellular soluble yellow tetrazolium dye MTT to insoluble violet formazan dye.

\section{Apoptosis/necrosis assay}

This procedure was performed in $500 \mu \mathrm{L}$ siliconized tubes; each tube consisted of $4 \times 10^{6}$ cells at the start of the procedure to compensate for cell loss. 


\section{Cell Preparation}

After incubation and detaching of fibroblast with $0.25 \%$ trypsin-EDTA, cells were distributed on the used siliconized tubes. Samples were centrifuged at $335 \mathrm{x}$ g for 10 minutes and supernatant fluid was poured, then suspended in $2 \mathrm{~mL}$ 1x PBS (no calcium, no magnesium). Centrifugation and suspension were repeated three times, first suspension was in PBS and the following two times were in $1 \mathrm{~mL} 1 \mathrm{x}$ Annexin V binding buffer (BioLegend, California, USA). The three different intracanal medicaments were added to the tubes and incubated at $37^{\circ} \mathrm{C}$ in humidified $95 \%$ air and 5\% CO2 for $24 \mathrm{~h}$.

\section{Application of Annexin V/Propidium Iodide Stain}

Annexin V (5 $\mu \mathrm{L})$ (BioLegend, California, USA) was added to each tube, and then tubes were incubated in the dark for 15 minutes at room temperature. 100 $\mu \mathrm{L}$ of $1 \mathrm{x}$ Annexin $\mathrm{V}$ binding buffer was added to each reaction tube. $4 \mu \mathrm{L}$ of propidium iodide (PI) (BioLegend, California, USA) that has been diluted (1:10 in 1x Annexin V binding buffer) was added to the reaction tube. Tubes were then incubated in the dark for 15 minutes at room temperature. 500 $\mu \mathrm{L}$ 1x Annexin $\mathrm{V}$ binding buffer was added to wash the cells. Samples were centrifuged at $335 \mathrm{x} g$ for 10 minutes and the supernatant was decanted. Cells were resuspended in $500 \mu \mathrm{L}$ 1x Annexin V binding buffer and $500 \mu \mathrm{L} 2 \%$ formaldehyde to create a $1 \%$ formaldehyde (fixative) solution. Thereafter, samples were fixed on ice for 10 minutes, stored overnight at $4^{\circ} \mathrm{C}$ in the dark, then $1 \mathrm{~mL} 1 \mathrm{x}$ PBS was added to each tube, and mixed by flicking. Centrifugation at $425 \mathrm{xg}$ for 8 minutes with pouring of supernatant two times. This was repeated two more times. Finally, tubes were incubated for $15 \mathrm{~min}$ at $37^{\circ} \mathrm{C}$.

Samples were analyzed on a fluorescenceactivated cell sorter (FACS) flow cytometer (Beckman Coulter Diagnostics, Indiana, USA).
This software allows assessing specific populations, individualized by gates according to size (FSC), granularity (SSC), and fluorescence (FL) parameters. Early apoptotic cells stained positively with annexin $\mathrm{V}$, whereas late apoptotic cells stained positively with annexin V and PI. Percentages of viable cells, apoptotic cells and necrotic cell populations were determined as described by Vermes et al., ${ }^{(22)}$. The experiment was done in duplicates.

\section{RESULTS}

\section{MTT-dye reduction assay}

\section{A. Comparison between different concentrations in each intracanal medication (Intragroup analysis)}

There was a statistically significant difference between all concentrations in all the three experimental groups. Cytotoxicity of the three medicaments was directly proportional with the concentrations as the percentage of viable cells increase with decreasing the concentrations (Fig. 2).

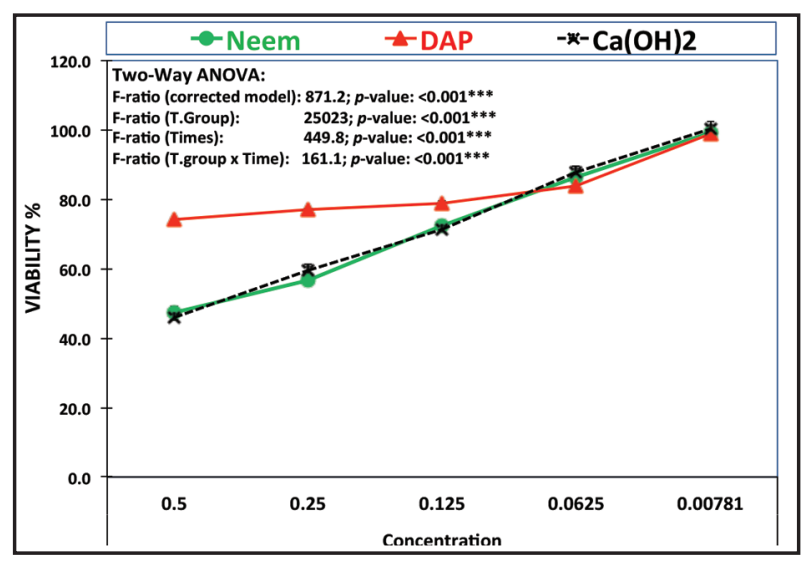

Fig. (2) Line curve showing comparison between the change in viability (\%) (Y-axis) under the effect of increasing concentration (X-axis). 
B. Comparison between three intracanal medications at different concentrarions (Intergroup analysis) the level of significance was set at $<0.05$.

In the current study, at concentrations 0.5 , 0.25 and $0.125 \mathrm{mg} / \mathrm{mL}$, DAP recorded the highest significant of viable cell recording $74 \%, 77 \%$ and $79 \%$ for each concentration respectively. At lower concentration $0.0625 \mathrm{mg} / \mathrm{mL}$, the three medicaments (DAP, $\left.\mathrm{Ca}(\mathrm{OH})_{2}, \mathrm{Neem}\right)$ were slightly cytotoxic. However, at concentration $0.00781 \mathrm{mg} / \mathrm{mL}$ there was no significant difference between the three intracanal medications, all three medicaments were biocompatible and were considered non cytotoxic with viable cells concentration $>90 \%$ (Fig. 3).

\section{Apoptosis/necrosis assay}

Regarding the healthy apoptotic cells, DAP showed the statistically significant highest mean value followed by $\mathrm{Ca}(\mathrm{OH})_{2}$ then Neem oil. On the other hand, the early and late apoptotic cells, Neem oil exhibited the statistically significant highest apoptotic rate and necrosis, followed by $\mathrm{Ca}(\mathrm{OH})_{2}$. Meanwhile DAP exhibited the statistically significant lowest apoptotic rate (Fig. 4, Fig. 5).

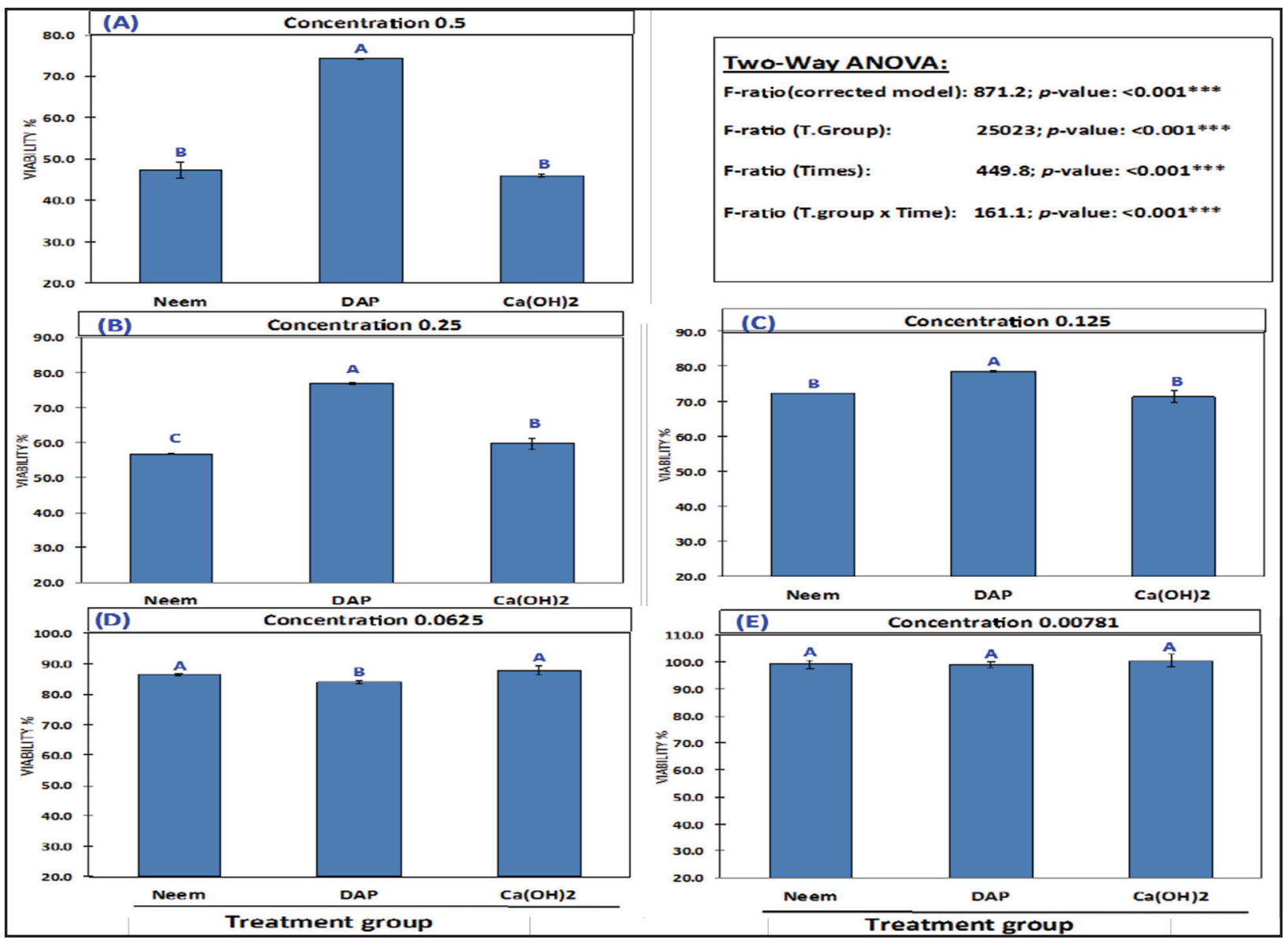

Fig. (3) Bar chart showing viability \% at different treatment groups $\left(\mathrm{Neem}, \mathrm{DAP}\right.$, and $\left.\mathrm{Ca}(\mathrm{OH})_{2}\right)$ tested at all concentration $(0.5$, $0.25,0.125,0.0625,0.00781 \mathrm{mg} / \mathrm{mL}$ ). 


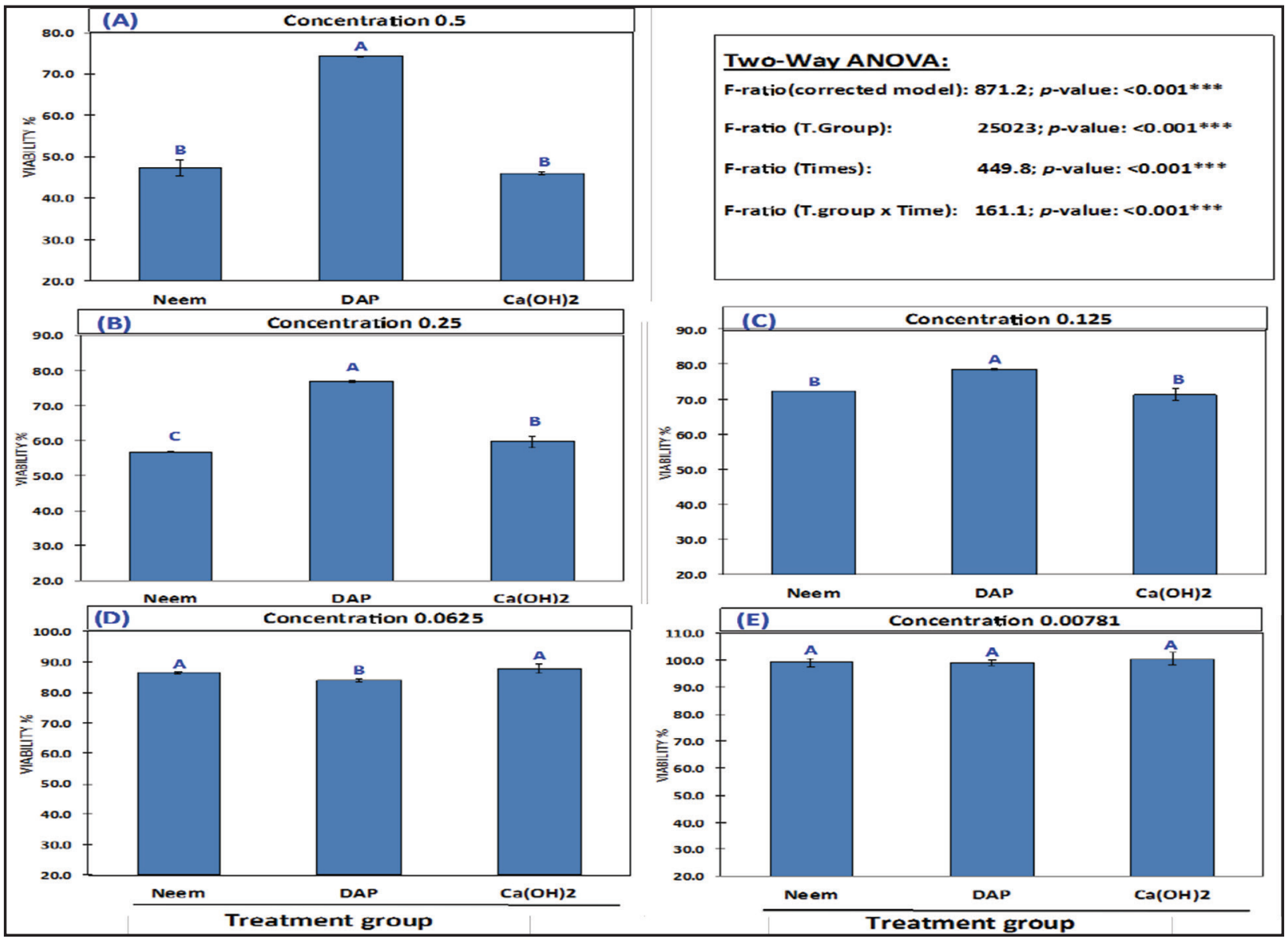

Fig. (4) Bar chart showing comparison between the mean change values of the apoptotic levels of the three intracanal medications.

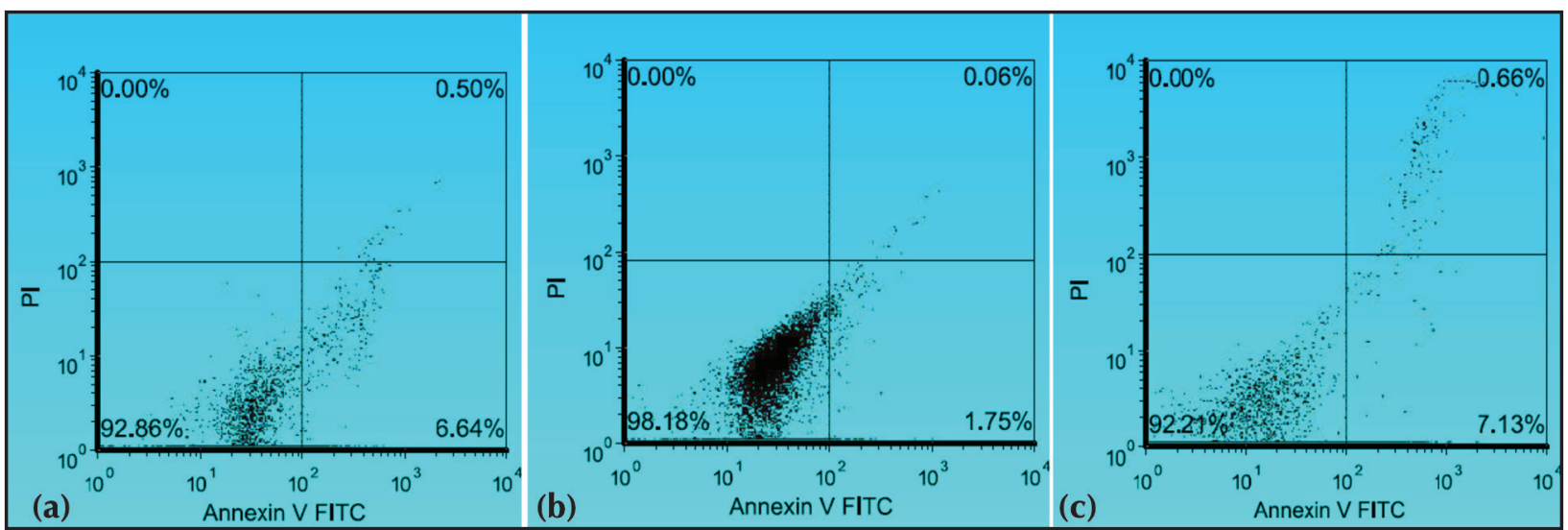

Fig. (5) Contour diagram of FITC-Annexin V/PI flow cytometry of HGFC after exposing to three different intracanal medications (a) $\mathrm{Ca}(\mathrm{OH})_{2}$, (b) DAP, (c) Neem Oil.The lower left quadrants of each panels show the viable cells, which exclude PI and are negative for FITC-Annexin V binding. The upper right quadrants contain the non-viable, necrotic cells, positive for FITC-Annexin V binding and for PI uptake. The lower right quadrants represent the apoptotic cells, FITC-Annexin V positive and PI negative demonstrating cytoplasmic membrane integrity. 


\section{DISCUSSION}

A wide variety of intracanal medications is available. The most common is $\left(\mathrm{Ca}(\mathrm{OH})_{2}\right)$ and its combination with other materials such as iodoform. Antibiotics also have gained popularity especially with the need of a broad spectrum antimicrobial agent for disinfection in regenerative endodontics which relies mainly on the action of irrigants and intracanal medicaments. These medications are proved to be effective antibacterial agents under laboratory conditions, but their efficacies in clinical use are unpredictable and exhibit a degree of toxicity and allergic reactions that may cause tissue injury. Recent trend toward using medication extracted from natural plants has increased rapidly to overcome the drawbacks of the commercially available intracanal medicaments ${ }^{(23)}$.

Neem has been proven to be a powerful antimicrobial agent by inhibiting the increase of microorganisms which cause infectious diseases. It is also characterized by its anti-adherence activity as it alters bacterial adhesion and ability of the microorganisms to colonize ${ }^{(24)}$.

Intracanal medications must be biocompatible because they come into direct contact with periapical tissues during endodontic treatment either by extrusion through the apex or leaching of the fine particles overtime ${ }^{(5)}$, otherwise these medications can result in high levels of inflammation, which can induce tissue destruction ${ }^{(26)}$. Therefore, these drugs should be able to induce repair of the injured area without interfering with osteogenesis and cementogenesis ${ }^{(26)}$.

MTT is one of the most commonly applied colorimetric assays for evaluation of cell viability and cytotoxicity of several drugs at different concentrations ${ }^{(7)}$. However, the sensitivity of an MTT assay is lower than that of fluorescent or luminescent assays, as MTT reduction assay is a marker reflecting viable cell metabolism and not specifically cell proliferation ${ }^{(27)}$. Therefore, Annexin $\mathrm{V}$ apoptosis/necrosis assay has been added to this study as it allows easy and sensitive analysis of the changes in the structure of cell membrane with the application of fluorescence methods. In this way vital, apoptotic and dead cells can be distinguished and analyzed by flow-cytometry microscopy ${ }^{(28)}$.

When evaluating cytotoxic effect of different intracanal medicaments, cell type is an important factor for consideration. Human gingival fibroblasts were used in this experiment due to their quick and easy growth ${ }^{(29)}$, in addition to their availability in periapical tissues and the periodontal ligament, which are areas susceptible to the effects of intracanal medications and their degradation products. Fibroblasts are also the largest producers of collagen tissue and, therefore, actively participate in periapical tissue repair process ${ }^{(30)}$.

In MTT dye reduction assay, the intergroup analysis showed statistically significant difference between the tested groups $\mathrm{Ca}(\mathrm{OH})_{2}$ and Neem oil at concentrations $(0.5$ and $0.25 \mathrm{mg} / \mathrm{mL})$ with obvious toxicity to the fibroblasts. For DAP, the four concentrations $(0.5,0.25,0.125$ and 0.0625 $\mathrm{mg} / \mathrm{mL}$ ) were slightly cytotoxic to fibroblasts. However, at concentration $0.00781 \mathrm{mg} / \mathrm{mL}$ there was no significant difference between the three intracanal medications, where all materials were biocompatible.

These findings were consistent with previous studies ${ }^{(31,32)}$ which evaluated the effect of different concentrations of DAP on the survival rate of human dental pulp stem cells (DPSC) using LDH assay and found that the three lowest tested concentrations of DAP $0.5,0.25$ and $0.125 \mathrm{mg} / \mathrm{mL}$ were non-toxic to DPSC. Same findings affirmed by Kim et al., ${ }^{(23)}$ who evaluated the dentin treated with two concentrations 
of DAP $(0.5$ and $1 \mathrm{mg} / \mathrm{mL})$ and EDTA regarding the proliferation of DPSCs and found that there was no significant differences in the proliferation of DPSCs with both concentration regardless of the use of EDTA.

Regarding, the reaction of $\mathrm{Ca}(\mathrm{OH})_{2}$ to fibroblast, it showed moderate cytotoxicity at concentration $0.5 \mathrm{mg} / \mathrm{mL}$. While at concentrations $0.25,0.125$ $\mathrm{mg} / \mathrm{mL} \mathrm{Ca}(\mathrm{OH})_{2}$ displayed slight cytotoxicity. This could be referred to the direct relation between the $\mathrm{pH}$ and the concentration of the drug, as the $\mathrm{pH}$ decreases when using lower concentration, consequently, cytotoxicity of $\mathrm{Ca}(\mathrm{OH})_{2}$ decreased by using decreased concentration ${ }^{(33)}$.

Neem oil displayed moderate cytotoxicity at concentration $0.5 \%$ and remained at same level of cytotoxicity at concentration $0.25 \mathrm{mg} / \mathrm{mL}$. This could be explained by the Neem formula used in this study design, which was $100 \%$ pure cold pressed and it is well known that its effect is concentration dependent ${ }^{(34,35)}$, so the side effects increase when the concentration increase. In addition, Franco $\boldsymbol{e t}$ $a l .{ }^{(36)}$ reported that when using Neem oil in medical and dental conditions or in connective tissue disorders it should be diluted with water because the concentration is a crucial point.

The MTT results were parallel to the Apoptosis/ necrosis assay, where DAP group showed the statistically significant highest mean value of healthy apoptotic cells $(98.213 \pm .027)$ followed by $\mathrm{Ca}(\mathrm{OH})_{2}$ then Neem oil. These results might be attributed to the metronidazole present in the formula of DAP that has no cytotoxic effect on stem cells ${ }^{(18,37)}$. Also, might be due to glycerin involved in DAP formula which is considered biocompatible ${ }^{(38,39)}$.

Regarding the early and late apoptotic cells, Neem oil exhibited the highest apoptotic rate compared with other medicaments. These findings could be explained by the antitumor nature of $\mathrm{Neem}^{(\mathbf{4 0 )}}$ that induces apoptosis and leads to cell mortality ${ }^{(41)}$. It has been demonstrated that Neem alters cell cycle and prompts apoptosis in various carcinoma via both extrinsic and intrinsic apoptotic pathways ${ }^{(42)}$. We rejected the null hypothesis as there was significant difference between the cytotoxicity of the three tested intracanal medications $\left(\mathrm{Ca}(\mathrm{OH})_{2}\right.$, DAP, Neem oil) $(P$-value $<0.001)$.

\section{CONCLUSION}

In terms of MTT assay; cytotoxicity of the three medicaments was directly proportional with the concentrations as the percentage of viable cells increases with decreasing the concentration.

\section{REFERENCES}

1. Sato T, Hoshino E, Uematsu H, Kota K, Iwaku M and Noda T. Bactericidal efficacy of a mixture of ciprofloxacin, metronidazole, minocycline and rifampicine against bacteria of carious and endodontic lesions of human deciduous teeth. Microb Ecol Health Dis. 1992; 5:171-177.

2. Chong BS and Pitt Ford TR. The role of intracanal medication in root canal treatment. Int Endod J. 1992; 25:97-106.

3. Heward S and Sedgley C. Effects of intracanal mineral trioxide aggregate and calcium hydroxide during four weeks on $\mathrm{pH}$ changes in simulated root surface resorption defects: an in vitro study using matched pairs of human teeth. J Endod. 2011; 37:40-44.

4. Yoshino P, Nishiyama CK, Modena KC, Santos CF and Sipert CR. In vitro cytotoxicity of white MTA, MTA Fillapex and Portland cement on human periodontal ligament fibroblasts. Braz Dent J. 2013; 24:111-116.

5. Hauman Ch and Love RM. Biocompatibility of dental materials used in contemporary endodontic therapy: a review. Part 1. Intracanal drugs and substances. Int Endod J. 2003; $36: 75-85$

6. Hauman $\mathrm{CH}$ and Love RM. Biocompatibility of dental materials used in contemporary endodontic therapy: a 
review. Part 2. Root-canal-filling materials. Int Endod J. 2003;36:147-160.

7. Sliwka L, Wiktorska K, Suchocki P, Milczarek M, Mielczarek S, Lubelska $\mathrm{K}$, Cierpiał $\mathrm{T}$, Łyżwa $\mathrm{P}$, Kiełbasiński P, Jaromin A, Flis A and Chilmonczyk Z. The comparison of MTT and CVS assays for the assessment of anticancer agent interactions. PLoS One. 2016; 11-16.

8. Mosmann T. Rapid colorimetric assay for cellular growth and survival: application to proliferation and cytotoxicity assays. J Immunol Methods. 1983; 65:55-63.

9. Van de Loosdrecht AA, Beelen RH, Ossenkoppele GJ, Broekhoven MG and Langenhuijsen MM. A tetrazoliumbased colorimetric MTT assay to quantitate human monocyte mediated cytotoxicity against leukemic cells from cell lines and patients with acute myeloid leukemi. J Immunol Methods. 1994; 174:311-320.

10. Martinez MM, Reif RD and Pappas D. Detection of apoptosis: a review of conventional and novel techniques. Anal Methods. 2010; 2:996-1004.

11. Boersma HH, Kietselaer BL, Stolk LM, Bennaghmouch A, Hofstra L, Narula J, Heidendal GA and Reutelingsperger CP. Past, present, and future of annexin A5: from protein discovery to clinical applications. J Nucl Med. 2005; 46:2035-2050.

12. Hanshaw RG and Smith BD. New reagents for phosphatidylserine recognition and detection of apoptosis. Bioorg Med Chem. 2005; 13:5035-5042.

13. Hidalgo E and Domingues C. Mechanisms underlying chlorhexidine- induced cytotoxicity. Toxicol In Vitro. 2001; 15:271-276.

14. Hoshino E, Kurihara-Ando N, Sato I, Uematsu H, Sato M, Kota $\mathrm{K}$ and Iwaku M. In-vitro antibacterial susceptibility of bacteria taken from infected root dentine to a mixture of ciprofloxacin, metronidazole and minocycline. Int Endod J. 1996; 29:125-130.

15. Iwaya SI, Ikawa M and Kubota M. Revascularization of an immature permanent tooth with apical periodontitis and sinus tract. Dent Traumatol. 2001; 17:185-187.

16. Desai S and Chandler N. Calcium hydroxide based root canal sealers: A Review. J Endod. 2009; 35:475-480.

17. Wilson A. Severe tissue necrosis following intra-arterial injection of endodontic calcium hydroxide: a case series.
Oral Surg Oral Med Oral Pathol Oral Radiol Endod. 2008; 105:666-669.

18. Chuensombat S, Khemaleelakul S, Chattipakorn S and Srisuwan T. Cytotoxic effects and antibacterial efficacy of a 3-antibiotic combination: an in vitro study. J Endod. 2013; 39:813-819.

19. Biswas K, Chattopadhyay I, Banerjee RK and Bandyopadhyay U. Biological activities and medicinal properties of neem [Azadirachta indica]. Curr Sci. 2001; 82:1336-1345.

20. Fayyad DM. Cytocompatibility of new bioceramic-based materials on human fibroblast cells (MRC-5). Oral Surg Oral Med Oral Pathol Oral Radiol Endod. 2011; 112:137-142.

21. Schmalz G. Concepts in biocompatibility testing of dental restorative materials. Clin Oral Invest.1997; 1:154-162.

22. Vermes I, Haanen C, Steffens-Nakken $\mathrm{H}$ and Reutelingsperger C. A novel assay for apoptosis.Flow cytometric detection of phosphatidylserine expression on early apoptotic cells using fluorescein labelled annexin V. J Immunol Methods. 1995; 184:39-51.

23. Sharad K, Rajeev K and Saraf P. Role of herbs in endodontics: An update. Endodontology. 2011; 23:96-100.

24. Nayak A, Nayak RN, Saumya G, Bhatt K and Kudalkar K. Evaluation of antibacterial and anticandidal efficacy of aqueous and alcoholic extract of neem (Azadirachta indica) an in vitro study. Int J Res Ayurveda Pharm. 2011; 2:230-235.

25. Yoshino P, Nishiyama CK, Modena KC, Santos CF and Sipert CR. In vitro cytotoxicity of White MTA, MTA Fillapex and Portland cement on human periodontal ligament fibroblasts. Braz Dent J 2013; 24:111-116.

26. Camargo SE, Camargo CH, Hiller KA, Rode SM, Schweikl H and Schmalz G. Cytotoxicity and genotoxicity of pulp capping materials in two cell lines. Int Endod J. 2009; 42:227-237.

27. Huyck L, Ampe C and Van Troys M. The XTT cell proliferation assay applied to cell layers embedded in three-dimensional matrix. Assay Drug Dev Tech. 2012; 10:382-392.

28. Boersma HH, Kietselaer BL, Stolk LM, Bennaghmouch A, Hofstra L, Narula J, Heidendal GA and Reutelingsperger CP. Past, present, and future of annexin A5: from protein discovery to clinical applications. J Nucl Med. 2005; 46:2035-2050. 
29. Hirschman WR, Wheater MA, Bringas JS and Hoen MM. Cytotoxicity comparison of three current direct pulpcapping agents with a new bioceramic root repair putty. J Endod. 2012; 38:385-388.

30. Silva EJ, Accorsi-Mendonca T, Almeida JF, Ferraz CC, Gomes BP and Zaia AA. Evaluation of cytotoxicity and up-regulation of gelatinases in human fibroblast cells by four root canal sealers. Int Endod J. 2012; 45:49-56.

31. Sabrah AH, Yassen GH, Liu WC, Goebel WS, Gregory RL and Platt JA. The effect of diluted triple and double antibiotic pastes on dental pulp stem cells and established Enterococcus faecalis biofilm. Clin Oral Investig. 2015; 19:2059-2066.

32. Krittika R. Antimicrobial Efficacy of Various Intracanal Medicaments against Enterococcus faecalis. J Pharm Sci \& Res. 2017; 9:1861-1863.

33. Alsalleeh F, Stephenson GL, Lyons N, Young A and Williams S. Human periodontal ligament cells response to commercially available calcium hydroxide pastes. Int J Dent Oral Sci. 2014; 2:6-9.

34. Chang ST, Wu JH, Wang SY, Kang PL, Yang NS and Shyur LF. Antioxidant activity of extracts from Acacia confusa bark and heartwood. J Agric Food Chem. 2001; 49:3420-3424.

35. Vanka A, Tandon S, Rao SR, Udupa N and Ramkumar P. The effect of indigenous Neem Azadirachta indica mouth wash on Streptococcus mutans and lactobacilli growth. Indian J Dent Res. 2001; 12: 133-144.

36. Franco P, Potenza I, Moretto F, Segantin M, Grosso M, Lombardo A, Taricco D, Vallario P, Filippi AR, Rampino
M and Ricardi U. Hypericum perforatum and neem oil for the management of acute skin toxicity in head and neck cancer patients undergoing radiation or chemo-radiation: a single-arm prospective observational study. Radiat Oncol. 2014; 9:297-303.

37. Althumairy R, Teixeira FB and Diogenes A. Effect of dentin conditioning with intracanal medicaments on survival of stem cells of apical papilla. J Endod. 2014; 40:521-525.

38. Zhang H, Hu Z, Huang L, Zhang H, Song K, Wang L, Shi Z, Ma J, Zhuang Y, Shen W, Zhang Y, Xu H and Tang Y. Dehydration of glycerol to acrolein over hierarchical ZSM-5 zeolites: effects of mesoporosity and acidity. ACS Catal. 2015; 5:2548-2558.

39. Mishra SK, Malik RK, Panwar H and Barui A. Microencapsulation of reuterin to enhance long-term efficacy against food-borne pathogen Listeria monocytogenes. Bio. 2018; 8:23-30.

40. Kastan MB and Bartek J. Cell-cycle checkpoints and cancer. Nature. 2004; 432:316-323.

41. Arakaki J, Suzui M, Morioka T, Kinjo T, Kaneshiro T, Inamine $\mathrm{M}$, Sunagawa $\mathrm{N}$, Nishimaki $\mathrm{T}$ and Yoshimi $\mathrm{N}$. Antioxidative and modifying effects of a tropical plant Azadirachta indica (Neem) on azoxymethane-induced preneoplastic lesions in the rat colon. Asian Pac J Cancer Prev. 2006; 7:467-471.

42. Priyadarsini RV, Murugan RS, Sripriya P, Karunagaran D and Nagini $\mathrm{S}$. The neem limonoids azadirachtin and nimbolide induce cell cycle arrest and mitochondria-mediated apoptosis in human cervical cancer (HeLa) cells. Free Radic Res. 2010; 44:624-634. 